\title{
Prospective Study of Gross and microscopic changes in 146 cases of Cryptorchid Testes at varied locations with particular reference to the incidence of Germ cell Tumours in Biopsy specimens
}

\author{
Shiekh Mahmood Rashid', Shera Tahleel Altaf', Shiekh Aamir Rashid ${ }^{3}$, Shera Altaf Hussain ${ }^{4}$, \\ Khan Ather Hafiz ${ }^{5}$
}

1.4 ${ }^{4}$ Department of General Surgey, ${ }^{2}$ Department of Radio Diagnosis, ${ }^{5}$ Department of Pathology, Govt. Medical College Baramulla ${ }^{3}$ ASCOMS, Jammu

\section{A B S T R A C T}

Background: Cryptorchidism or undescended testes is a commonly observed congenital anomaly of male children seen in patients presenting in general and pediatric surgical practice of our region. In this study, we prospectively studied 146 cases of undescended testes to statistically observe gross and microscopic changes in different such cases.

Objective: To study the gross and microscopic changes in cryptorchid testes at varied locations.

Methods: A hospital-based prospective study of 146 cases of undescended testes was done from November 2014 to December 2019 and the results of gross and microscopic changes in biopsy specimens were statistically analyzed.

Results: A total of 146 cases studied included $45.19 \%$ presenting at the age of 4 to 8 years and $25.34 \%$ presenting at the age of 8 to 14 years. The study revealed mild testicular atrophy in $6.16 \%$ of the cases and moderate to severe atrophy in $36.97 \%$. Epididymal and vassal anomalies were very rare in suprascrotal testes but common in high cryptorchid testes. Biopsy specimens showed the incidence of seminomas in $4.79 \%$ of intra-abdominal testes but the incidence was lesser in undescended testes at locations lower down.

Conclusion: A strong association was observed between the location of cryptorchid testes and observed gross and microscopic changes including malignant transformation.

Keywords: cryptorchidism, orchidopexy, testes, orchidectomy, testicular biopsy.

JMS: 2020; 23(2):26-31 DOI: https://doi.org/10.33883/jms.v23i2.744

\section{INTRODUCTION}

The term Cryptorchidism, derived from the Greek 'Cryptos', meaning 'hidden' is basically reserved for those testes that are truly obscure, usually within the abdominal cavity and 'incomplete descent' or 'maldescent' of the testis is the term reserved for those cases in which testis is arrested at some point in the normal course of its descent and is palpable on clinical examination; but in the present study 'Cryptorchidism' has been used as a general term to describe all types of undescended testes whether palpable or otherwise. Undescended testes are observed unilaterally or bilaterally in one to ten percent of male infants at birth but

\begin{tabular}{|l|l|}
\hline \multicolumn{2}{|c|}{ Access this article online } \\
\hline
\end{tabular}

the incidence decreases to 0.8 percent at the age of one year due to spontaneous testicular descent. ${ }^{(2-6)}$ The usual sites of arrest are at the internal inguinal ring, within the inguinal canal, or at the external inguinal ring. Recently, it has been suggested that testicular descent occurs in two stages with different anatomic and hormonal mechanisms for each stage. ${ }^{(7,8)}$ Cryptorchid testes especially those presenting very

Correspondence:

Dr. Shiekh Mahmood Rashid, MS

Associate Professor, Department of General Surgery

Govt. Medical College and Associated Hospital Baramulla,

Email:mahmoodshiekh234@gmail.com

How to cite this article: Shiekh M, Sheera T, Rashid SA rashid, Hussain SA, Hafiz KA. Prospective Study of Gross and microscopic changes in 146 cases of Cryptorchid Testes at varied locations with particular reference to the incidence of Germ cell Tumors in Biopsy specimens.JMS 2020; 23(2):26-31

Received: 2020-05-09 Accepted: 2020-06-22 
Rashid S M et al. Prospective Study of Gross and microscopic changes in 146 cases of Cryptorchid Testis

late as in rural settings of north Kashmir have been observed to be associated with gross anatomic abnormalities and microscopic changes especially diminished germ cell counts ${ }^{(17-20)}$ and malignant germ cell tumours (seminomas) ${ }^{(21-30)}$. The present study is focussed on the results of gross and microscopic alterations including malignant transformation in the testicular biopsy specimens of 146 cases of undescended testes belonging to various age groups operated at Govt. Medical College Baramulla during a five year period from Nov. 2014 to Dec. 2019.

\section{MATERIALAND METHODS}

This study included 146 male patients in the age group of 0 to 14 years operated in the department of General Surgery at Govt. Medical College Baramulla, Kashmir from Nov.2014 to Dec. 2019 for undescended testes at varied locations. The patient study was analyzed with respect to 1 . Age of the patient at presentation and type of cryptorchidism (right, left, or bilateral). An assessment of the precise location of the undescended testis, presence of any associated inguinal hernia, and an objective confirmation and degree of testicular atrophy, if any, was done by a pre-operative highresolution ultrasound done in the department of Radiodiagnosis of our institution.2. An assessment of gross testicular atrophy, vasal, and epididymal abnormalities was done postoperatively by gross testicular examination and measurement of testicular size by calipers and the results were analyzed with respect to the location of undescended testis and age of the patient at presentation. 3. Special focus was put on the histological changes like germ cell counts and malignant transformation in testicular biopsy specimens of the cases presenting for surgery and correlation between the location of cryptorchid testes and incidence of germ cell tumours was thus observed.

\section{OBSERVATIONS AND RESULTS}

In the present study, the maximum number of patients $(45.19 \%)$ presented at the age of 4 to 8 years, though a fairly large group of patients (25.34\%) presented later at the age of 8 to 14 years. In addition, most of the patients $(70.53 \%)$ were older than 4 years and many $(25.34 \%)$ were older than 8 years; the mean age at presentation was 6.7 years. The age distribution of patients was done in accordance with the incidence of undescended testes in different age groups. There was not a significant difference observed between the incidence of cryptorchid side to the age; the right side was involved in nearly one half $(50.00 \%)$ of the cases studied, the left side in $38.37 \%$ while in $11.64 \%$ of the cases, the cryptorchidism was bilateral (table 1).

Table 1: Relationship of the age of the patient and cryptorchidism type and location

\begin{tabular}{|l|l|l|l|}
\hline $\begin{array}{l}\text { Age } \\
(\text { years })\end{array}$ & $\begin{array}{l}\text { Right- } \\
\text { sided n(\%) }\end{array}$ & $\begin{array}{l}\text { Left-sided } \\
\text { n }(\%)\end{array}$ & $\begin{array}{l}\text { Bilateral } \\
\text { n }(\%)\end{array}$ \\
\hline $0-2$ & $9(6.16)$ & $5(3.42)$ & $2(1.37)$ \\
\hline $2-4$ & $12(8.22)$ & $10(6.84)$ & $5(3.42)$ \\
\hline $4-8$ & $34(23.28)$ & $25(17.12)$ & $7(4.79)$ \\
\hline $8-14$ & $18(12.33)$ & $16(10.96)$ & $3(2.05)$ \\
\hline Total & $\mathbf{7 3 ( 5 0 . 0 0 )}$ & $\mathbf{5 6 ( 3 8 . 3 7 )}$ & $\mathbf{1 7 ( 1 1 . 6 4 )}$ \\
\hline
\end{tabular}

The analysis of our results regarding cryptorchidism type and location in relation to the age of the patient revealed that the frequency of abdominal undescended testes decreases with increasing age $(p<0.1)$ while that of suprascrotal testes increases with increasing age $(\mathrm{p}<0.001)$ ( Table 2$)$.

Table 2: Cryptorchidism type and location in relation to age

\begin{tabular}{|l|l|l|l|l|}
\hline $\begin{array}{l}\text { Age } \\
\text { (Years) }\end{array}$ & $\begin{array}{l}\text { Abdominal } \\
\mathbf{n}(\%)\end{array}$ & $\begin{array}{l}\text { Internal } \\
\text { ring n } \\
(\mathbf{\%})\end{array}$ & $\begin{array}{l}\text { Intra } \\
\text { canalicularn } \\
(\mathbf{\%})\end{array}$ & $\begin{array}{l}\text { Suprascrotaln } \\
(\%)\end{array}$ \\
\hline $0-2$ & $2(1.37)$ & $6(4.11)$ & $5(3.42)$ & $3(2.05)$ \\
\hline $2-4$ & $3(2.05$ & $8(5.48)$ & $4(2.74)$ & $2(1.37)$ \\
\hline $4-8$ & $9(6.16)$ & $29(19.86)$ & $26(17.81)$ & $7(4.79)$ \\
\hline $8-14$ & $6(4.11)$ & $18(12.39)$ & $14(9.58)$ & $5(3.42)$ \\
\hline Total & $\mathbf{2 0 ( 1 3 . 7 0 )}$ & $\mathbf{6 1 ( 4 1 . 7 8 )}$ & $\mathbf{4 9 ( 3 3 . 5 6 )}$ & $\mathbf{1 6 ( 1 0 . 9 6}$ \\
\hline
\end{tabular}

The study of gross testicular atrophy in relation to the location of testis showed that most suprascrotalun descended testes were normal (fig 1) and mild testicular atrophy was observed in $6.16 \%$ of the cases while testes at intracanalicular, an internal ring, and abdominal positions (fig 2) showed moderate to severe atrophy (36.97\%). The results were statistically significant $(\mathrm{p}<0.0001)$ (Table 3$)$.

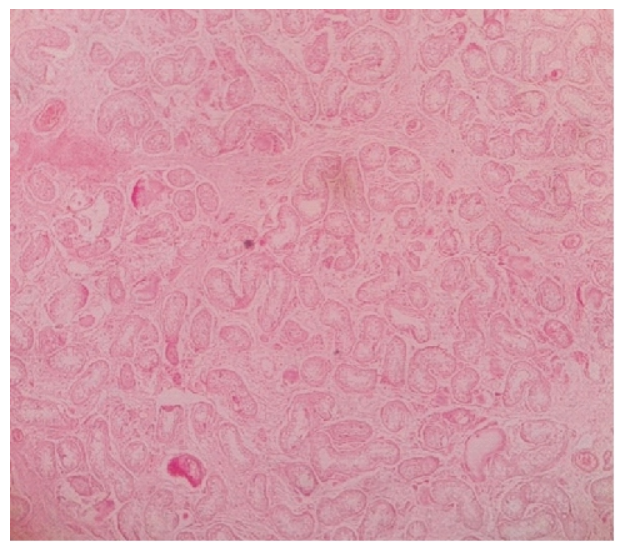

Fig 1: Normal histological picture (H\&E* 40) in a case of suprascrotal testes. 


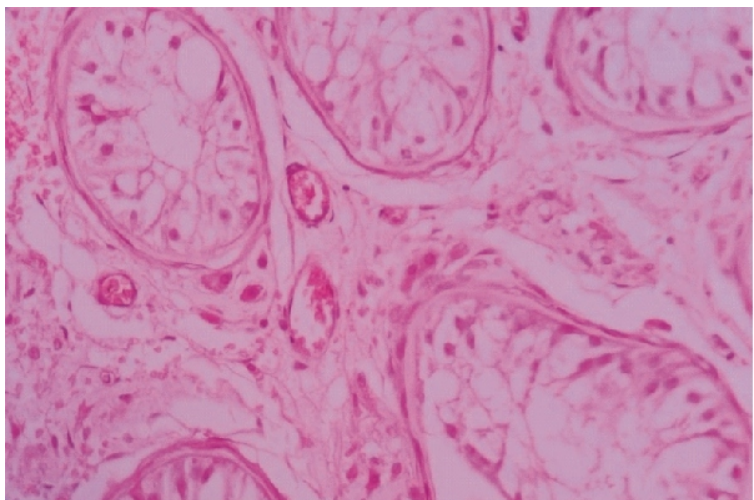

Fig 2: Intra- abdominal $\left(H \& E^{*} 400\right)$ atrophic testes.

Table 3: Gross estimation of testicular atrophy in relation to testes location

\begin{tabular}{|l|l|l|l|l|}
\hline $\begin{array}{l}\text { Testis } \\
\text { Location }\end{array}$ & $\begin{array}{l}\text { Total no of } \\
\text { cases n(\%) }\end{array}$ & $\begin{array}{l}\text { Mild } \\
\text { atrophy } \\
\mathbf{n}(\%)\end{array}$ & $\begin{array}{l}\text { Moderate } \\
\text { Atrophy } \\
\mathbf{n}(\%)\end{array}$ & $\begin{array}{l}\text { Severe } \\
\text { Atrophy } \\
\mathbf{n}(\%)\end{array}$ \\
\hline $\begin{array}{l}\text { Intra } \\
\text { abdominal }\end{array}$ & $20(13.70)$ & $2(1.37)$ & $6(4.11)$ & $9(6.16)$ \\
\hline Internal ring & $61(41.78)$ & $27(18.49)$ & $13(8.90)$ & $9(6.16)$ \\
\hline Intracanalicular & $49(33.56)$ & $23(15.75)$ & $11(7.53)$ & $6(4.11)$ \\
\hline Suprascrotal & $16(10.96)$ & $9(6.16)$ & $3(2.05)$ & $0(0.00)$ \\
\hline Total & $\mathbf{1 4 6}$ & $\mathbf{6 1 ( 4 1 . 7 8 )}$ & $\mathbf{3 3 ( 2 2 . 6 0 )}$ & $\mathbf{2 4 ( 1 6 . 4 4 )}$ \\
\hline
\end{tabular}

Most suprascrotal testes were either normal or had a mild extension and looping of epididymis $(1.36 \%)$ while the rest of the locations higher up (43.13\%) showed moderate or profound epididymala nomalies $(\mathrm{p}<0.0001)$. Similarly, vassal anomalies were very rare in suprascrotal testes $(1.36 \%)$ but common in high cryptorchid testes $(29.44 \%)$ (Table 4 showing different types of anomalies observed).

Table 4: Epididymal and vasal anomalies

\begin{tabular}{|l|l|l|l|l|}
\hline Testis location & $\begin{array}{l}\text { Total no } \\
\text { casesn (\%) }\end{array}$ & $\begin{array}{l}\text { Extendedloo- } \\
\text { pepididymisn } \\
(\%)\end{array}$ & $\begin{array}{l}\text { Vasextension } n \\
(\%)\end{array}$ & $\begin{array}{l}\text { Testicular } \\
\text { appendagesn } \\
(\%)\end{array}$ \\
\hline Intra abdominal & $20(13.70)$ & $6(4.10)$ & $9(6.16)$ & $6(4.11)$ \\
\hline Internal ring & $61(41.78)$ & $29(19.86)$ & $21(14.38)$ & $15(10.27)$ \\
\hline Itracanalicular & $49(33.56)$ & $28(19.17)$ & $13(8.90)$ & $24(16.44)$ \\
\hline Suprascrotal & $16(10.96)$ & $2(1.37)$ & $2(1.37)$ & $2(1.37)$ \\
\hline Total & $\mathbf{1 4 6}$ & $\mathbf{6 5}(\mathbf{4 4 . 5 2})$ & $\mathbf{4 5 ( 3 0 . 8 2 )}$ & $\mathbf{4 7 ( 3 2 . 1 9 )}$ \\
\hline
\end{tabular}

The histological findings of testicular biopsies in 53 cases that underwent either excision of the atrophic testis or a testicular biopsy revealed diminished germ cell and spermatogonia counts in $16.42 \%$ cases and normal counts in $5.48 \%$ of cases (table 5 ).
Table 5: Histological findings of 53 cases of truly undescended testes

\begin{tabular}{|l|l|l|l|l|l|}
\hline $\begin{array}{l}\text { Age } \\
\text { (years) }\end{array}$ & \multicolumn{2}{|l|}{ Orchidectomy specimens } & \multicolumn{2}{l|}{ Germ cell counts } & \\
\hline & $\begin{array}{l}\text { Artrophicn } \\
(\%)\end{array}$ & $\begin{array}{l}\text { No } \\
\text { parenchyman } \\
(\%)\end{array}$ & $\begin{array}{l}\text { Markedly- } \\
\text { decreasedn } \\
((\%)\end{array}$ & $\begin{array}{l}\text { Slightly- } \\
\text { decreasedn } \\
(\%)\end{array}$ & Normaln(\%) \\
\hline $0-2$ & $2(1.37)$ & $2(1.37)$ & $2(1.37)$ & $2(1.37)$ & $2(1.37)$ \\
\hline $2-4$ & $2(1.37)$ & $4(2.73)$ & $3(2.05)$ & $2(1.37)$ & $2(1.37)$ \\
\hline $4-8$ & $2(1.37)$ & $5(3.42)$ & $3(2.05)$ & $3(2.05)$ & $2(1.37)$ \\
\hline $8-14$ & $2(1.37)$ & $2(1.37)$ & $6(4.11)$ & $3(2.05)$ & $2(1.37)$ \\
\hline Total & $\mathbf{8 ( 5 . 4 8 )}$ & $\mathbf{1 3 ( 8 . 9 0 )}$ & $\mathbf{1 4}(\mathbf{9 . 5 9 )}$ & $\mathbf{1 0 ( 6 . 8 5 )}$ & $\mathbf{8 ( 5 . 4 8 )}$ \\
\hline
\end{tabular}

Histological findings also correlated with testis location. Markedly diminished germ cell counts were found in $12.17 \%$ of cases of higher cryptorchidism and $1.37 \%$ of suprascrotal testes. In contrast, normal germ cell counts were found in $6.16 \%$ of suprascrotal testes but only in $0.68 \%$ of cases of abdominal and Intracanacular testes. The rest of the cases studied $(6.85 \%)$ revealed moderate germ cell counts at both locations (Table 6).

Table 6: Histological findings of testicular biopsies in relation to testes location

\begin{tabular}{|l|l|l|l|}
\hline $\begin{array}{l}\text { Testis } \\
\text { location }\end{array}$ & $\begin{array}{l}\text { Markedly } \\
\text { decreased Germ } \\
\text { cell Counts n (\%) }\end{array}$ & $\begin{array}{l}\text { Slightly } \\
\text { decreased Germ } \\
\text { cell counts }\end{array}$ & $\begin{array}{l}\text { Normal Germ } \\
\text { cell } \\
\text { Counts n (\%) }\end{array}$ \\
\hline $\begin{array}{l}\text { High } \\
\text { (abdominal/ } \\
\text { canalicular) }\end{array}$ & $12(12.17)$ & $4(2.74)$ & $1(0.68)$ \\
\hline $\begin{array}{l}\text { Low } \\
\text { (suprascrot } \\
\text { al) }\end{array}$ & $2(1.37)$ & $6(4.11)$ & $9(6.16)$ \\
\hline Total & $\mathbf{1 4 ( 9 . 5 9 )}$ & $\mathbf{1 0 ( 6 . 8 5 )}$ & $\mathbf{1 0 ( 6 . 8 5 )}$ \\
\hline
\end{tabular}

The incidence of germ cell tumours on microscopic examination of 53 samples of orchidectomy/testicular biopsy specimens showed an incidence of $4.79 \%$ of seminomas in histological specimens of intraabdominaltestis while the samples were taken from high scrotal, inguinal canal and internal ring testis revealed an incidence of $0.00 \%, 2.05 \%$ and $2.74 \%$ respectively (Table 3 and 4) (Table 7).

Table 7. Incidence of Germ cell tumours (saminomas) on histological examination of biopsy specimens in relation to testes location

\begin{tabular}{|l|l|l|}
\hline Testes location & \multicolumn{2}{|l|}{ Incidence of Germ cell tumours } \\
\hline & Seminomasn (\%) & Others $\mathrm{n}(\%)$ \\
\hline Intra abdominal & $7(4.79)$ & $0(0.00)$ \\
\hline Internal ring & $4(2.74)$ & $0(0.00)$ \\
\hline Intracanalicular & $3(2.05)$ & $0(0.00)$ \\
\hline Suprascrotal & $0(0.00)$ & $0(0.00)$ \\
\hline Total & $\mathbf{1 4}(\mathbf{9 . 5 9 )}$ & $\mathbf{0 ( 0 . 0 0 )}$ \\
\hline
\end{tabular}




\section{Rashid S M et al. Prospective Study of Gross and microscopic changes in 146 cases of Cryptorchid Testis}

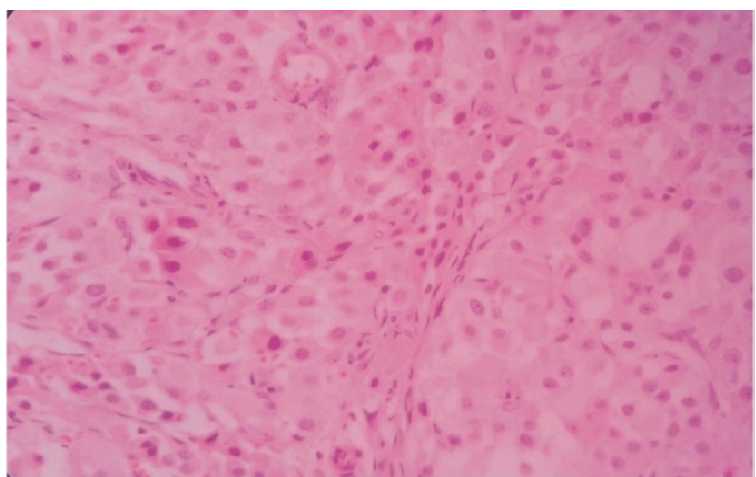

Fig 3: Seminoma $\left(H \& E^{*} 400\right)$ in a case of high inguinal testes

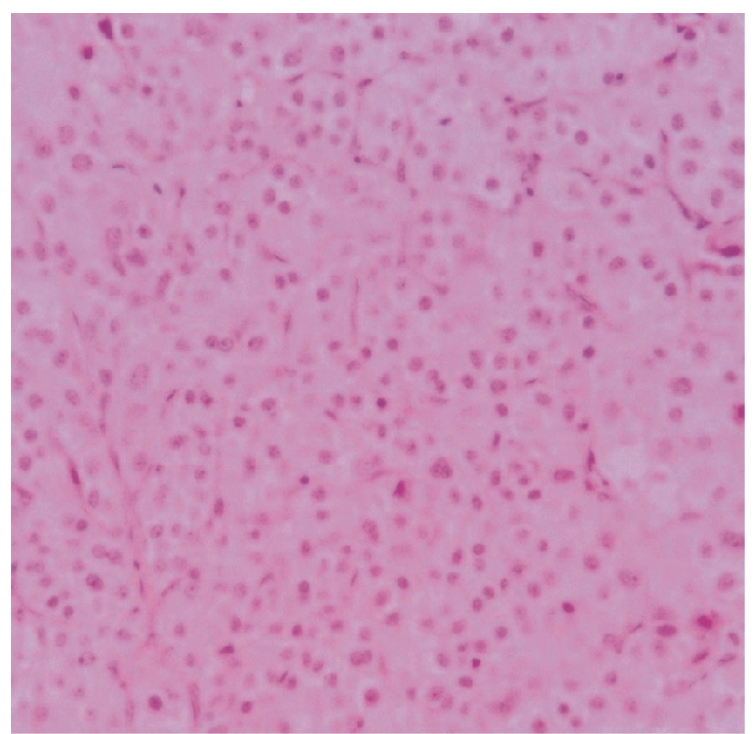

Fig 4: Seminoma $\left(H \& E^{*} 400\right)$ in a case of intra-abdominal testes

\section{DISCUSSION}

The first major finding from our study was that most of the patients $(70.57 \%)$ were older than four years and many $(25.38 \%)$ were older than eight years. Ignorance, social and ethical prejudices of patients in our social setup play an important role in delayed presentation and referral to a surgeon. The age distribution for the various sites of cryptorchid testes shows that with increasing age, the incidence of intra-abdominal testes decreases while the frequency of suprascrotal testes increases. This is due to the misconception of some parents and physicians that low cryptorchid testes may spontaneously descend later in childhood. Thus, patients with impalpable, intra-abdominal testes present earlier, while those with palpable suprascrotal testes wait longer hoping a spontaneous cure and are referred late before they seek medical assistance.

The gross morphological changes in the present study reveal moderate to severe atrophy of testes in intracanalicular and intra abdominal testes than those in suprascrotal position. The gross alterations of testicular volume and shape were accompanied by analogous microscopic findings (diminished germ cell counts, hypoplasia or atrophy) thereby revealing that the pathological changes parallel with gross morphological findings. There were markedly diminished germ cell counts in high cryptorchid testes than in those in suprascrotal position. In addition, older children more often showed significantly diminished germ cell counts than younger children and infants. These observations are correlating with previous studies showing that the location of cryptorchid testes and patient age at the time of orchidopexy are the major determinants of subsequent fertility in these individuals. ${ }^{9}$

Most of the undescended testes in suprascrotal position were normal or had a mild extension and looping of epididymis $(1.37 \%)$ while most of the intracanalicular, internal ring and abdominal testis showed moderate or profound epididymal anomalies (table 4 for different types of anomalies observed) $(35.13 \% ; \mathrm{P}<0.0001)$. Similar observations have been made in other studies as well wherein it has been found that gross alterations of epididymis and vas frequently accompany cryptorchidtestes $^{(22,23)}$.

The incidence of testicular germ cell tumours (seminomas) observed in our study in suprascrotal, intracanalicular and internal ring positions was very $\operatorname{low}(0.00 \%, 2.05 \%$ and $2.74 \%$ respectively; $\mathrm{P}<.001$ ) while in case of intra abdominal testis it showed a significantly higher incidence of $4.79 \%(\mathrm{P}<.0001)$. The higher incidence of testicular germ cell tumors in cryptorchid testes notably seminomas are due to the transformation of primordial germ cells (PGCs) into pluripotent germ cells which develop into precursor cancer cells. At an abnormal location, especially an intra abdominal one, the primordial germ cells also known as gonocytes continue to proliferate or undergo improper differentiation, resulting in a higher incidence of testicular germ cell tumors at these locations. ${ }^{(21-30)}$

\section{CONCLUSION}

Considering all these facts, it is thus concluded that cryptorchid testes are associated with gross morphological derangements as well as histological changes especially diminished germ cell counts and malignant transformation at locations higher up and even though the necessity of early 
Rashid S M et al. Prospective Study of Gross and microscopic changes in 146 cases of Cryptorchid Testis

surgical correction is well established, still patients, especially in the northern region of Kashmir valley, tend to present very late with consequent increased risks of infertility and malignant transformation.

Conflict of interest: Nil

Financial Support: Nil

Written Informed consent: Taken

\section{REFERENCES}

1. Kolon TF, Herndon CDA, Baker LA, et al. Evaluation and treatment of cryptorchidism: American urological association guidelines; 2014; 95: 62022.

2. Frey HL, Raijfer J: Incidence of cryptorchidism. UrolClin North Am 9:327, 1982.

3. Ramareddy RS, Alladi A, Siddappa OS. Ectopic testis in children: experience with seven cases. J Pediatr Surg. 2013; 48: 538-41.

4. Chilvers C, Pike MC et al: Apparent doubling of the frequency of undescended testis in England and wales in 1962-81. Lancet 2:330, 1984.

5. Cortes D, Thorup J: The incidence of maldescneded testes in Denmark. Paed Surg Int 5:2, 1990.

6. Gough MH. Cryptorchidism.Br J Surg 76: 109, 1989.

7. Hedzixelimovic F, Herzog B: Cryptorchidism. Pediatr Surg Int 2:132, 1987.

8. Scorer GC, Farrington GH (1971): Congenital deformities of the testis and the epididymis. Butterworths, London.

9. Candron M, Keating MA, Huff DS, et al: Cryptorchidism orchidopexy and infertility. A Critical long term retrospective analysis.J Urol 142:559, 1989.

10. Ritzen EM. Undescended testis; a consensus on management. Eur J Endocrinol. 2008: 159(suppl. 1): S87-90.

11. HeynsCF : The gubernaculum during testicular descent in the human fetus. J Anat 153:93, 1982.

12. Hutson J (1994): New insights in testicular descent. Paediatr Surg Int 9:541.

13. Turek PJ, Ewalt DH, Snyder HM et al (1994): Normal epididymal anatomy in boys. J Urol 151: 726-727.

14. Kogan S (1992): Cryptorchidism. In: Kelalis PP, King LR, Belman AB (eds) Clinical Paediatric Urology. WB
Saunders, Philadelphia, pp 1050-1083

15. Mollacian M, Mehrabi V, Elahi B (1994): Significance of edpidymal and ductal anomalies associated with undescended testis: study in 652 cases. Urology 43:857-860.

16. Miliaras D, Koutsoumis G, Vlahakis-Miliaras E (1995): Appendix testis and appendix epididymis:incidental findings in inguinal hernia and cryptorchidism operations. PediatrSurgInt 10:241242.

17. Abeyaratne MR, Aherne WA, Scott JES.The vanishing testis.Lancet.1969; 2: 822-4.

18. Lala R, de Sanctis C, Canavese F, Bardini T, Hadziselimovic F (1992). Early medical and surgical treatment of cryptorchidism: clinical , anatomic, and histologic findings. PediatrSurgInt 7:368-371.

19. Rajfer J, WalshPC (1977): Testicular descent. Original article series. The National Foundation, vol. XII, no. 2:107-122.

20. Thorup J, Cortes D, Nielson OH (1993): Clinical and histopathological evaluation of operated maldescended testes after luteinizing hormonereleasing hormone treatment. PediatrSurgInt 8:419422.

21. Akre O., Pettersson A., Ridhiardi L. (20090. Risk of contralateral testicular cancer among men with unilaterally undsecnended testis: a meta analysis. Int. J. Cancer 124, 687-68910.1002/ijc. 23936.

22. Barteczko K. J., Jacob M. I. (2000). The Testicular descent in human.Origin, development and fate of the gubernaculum Hunteri, processus vaginalis peritonei, and gonadal ligaments. Adv. Anat. Embryol Cell. Biol. 156, 1-9810.1007/978-3-642-58353-7_1.

23. Barthold J. S., Gonzalez R. (2003). The epidemiology of congenital cryptorchidism, testicular ascent and orchiopexy. J. Urol 170, 2396-240110.1097/ 01.ju.0000095793.04232.d8.

24. Hutson JM, Hasthorpe S. Testicular descent and cryptorchidism; the state of the art in 2004.J Pediatr Surg. 2005; 40: 297-302.

25. Adham I.M., Agoulnik A.I (2004). Insulin-like 3 signalling in testicular descent. Int. J. Androl. 27, 257- 
Rashid S M et al. Prospective Study of Gross and microscopic changes in 146 cases of Cryptorchid Testis

26510.1111/j.1365-2605.2004.00481.x

26. Bay K., Main K.M., Toppari J., Skakkebaek N. E. (2011). Testicular descent: INSL3, testosterone, genes and the intrauterine milieu. Nat. Rev. Urol. 8, 18719610.1038/nrurol.2011.23.

27. Boisen K.A., Kaleva M., Main K. M., Virtanen H. E., Haavisto A. M., Schmidt I. M., et al. (2004). Difference in prevalence of congenital cryptorchidism in infants between two Nordic countries. Lancet 363, 1264126910.1016/S0140-6736(04)15998-9

28. Chaganti R.S., Houldsworth J. (1998). The cytogenetic theory of the pathogenesis of human adult male germ cell tumours. APMIS 106, 80-83; discussion 8384.10.1111/j.1699-0463.1998.tb01322.x

29. Clark A. T. (2007). The stem cell identity of testicular cancer. Stem Cell. Rev. 3, 49-5910.1007/s12015-0070002-x

30. Cortes D., Thorup J., Petersen B. L. (2004). Testicular neoplasia in undescended testis of cryptorchid boys: does surgical strategy have an impact on the risk of invasive testicular neoplasia? Turk. J. Pediatr. 46 (Suppl.),35-42 